\title{
ANALYSIS OF THE DISTRIBUTION SYSTEM CONSTRUCTION COMPANY OFFERING THE SERVICE OF DISTRIBUTION OF FERTILIZER
}

\author{
AGNIESZKA MATUSZCZAK
}

University of Szczecin, POLAND

Wydział Zarządzania i Ekonomiki Usług

e-mail: agnieszka.matuszczak@wzieu.pl

RECEIVED
ACCEPTED
JEL
CLASSIFICATION

KEYWORDS

ABSTRACT

\author{
1 September 2017 \\ 15 December 2017 \\ D22, D30, D43
}

service distribution, fertilizer industry, distribution system

Logistic systems of enterprises are characterized by individual character, adapted to the type of business and the industry in which they operate, as well as their internal specifics. Shaping the system seeks to determine which entities, as well as the extent to which influence the structure and functioning of distribution channels specific products and the operation of the entire system. In his paper the author will analyze the concepts related to the distribution system and its specificity and, above all, show the way media distribution services of fertilizers on the market.

\section{Introduction}

Logistic systems of enterprises are characterized by individual character, adapted to the type of business and the industry in which they operate, as well as their internal specifics. Shaping the system seeks to determine which entities, as well as the extent to which influence the structure and functioning of distribution channels specific products and the operation of the entire system. The market of mineral fertilizers in Poland has a certain specificity, 
because the demand side is a large number of entities, while supply is represented mainly by units of the oligopolistic nature, hence, the market is regulating the flow of consumer products. In addition, fertilizer industry is characterized by seasonality and weather changes that is determined by the current financial conditions of final consumers, these factors influence the distribution of the service offered.

\section{Theoretical aspects of the distribution systems}

Each enterprise logistics system is characterized by high complexity and specificity, depending on the type of enterprise, the scope of its activities or manufactured goods make up the distribution channels it along with their links, functions and participants. A review of the definition of the distribution system is presented in Table 1.

Table 1. Overview of selected definition of the supply chain

\begin{tabular}{clll}
$\begin{array}{c}\text { Publication } \\
\text { date }\end{array}$ & Author & Name of the publication & \multicolumn{1}{c}{ Definition } \\
\hline 2009 & R.J. Best & $\begin{array}{l}\text { Market - Based } \\
\text { Management }\end{array}$ & $\begin{array}{l}\text { The system through which the company provides its products is a marketing system, } \\
\text { a combination of distribution channels and after-sales efforts }\end{array}$ \\
\hline 2001 & A. Czubała & Dystrybucja produktów & $\begin{array}{l}\text { The structure of the distribution system is the distribution channels and physical distribution, } \\
\text { the physical flow of products }\end{array}$ \\
\hline 2000 & T. Sztucki & $\begin{array}{l}\text { Marketing } \\
\text { przedsiębiorcy } \\
\text { i menedżera }\end{array}$ & $\begin{array}{l}\text { The distribution enterprises create distribution channels, which are used to a structured flow } \\
\text { of products from manufacturers to end customers }\end{array}$ \\
\hline & T. Kramer & Podstawy marketingu & $\begin{array}{l}\text { As part of the distribution system are, on the one hand, activities such as transport, storage, } \\
\text { maintenance and refinement of products that are associated with the physical transfer } \\
\text { of goods from the producer to the final consumer, on the other activities related to the } \\
\text { determination of the number and type of cells mediating in the distribution process, and also } \\
\text { set up tasks for each participant in this process }\end{array}$ \\
\hline
\end{tabular}

Source: own study.

Therefore, the logistics distribution functions performed by the company are varied (Gołembska, 2010) and different is the number of intermediate links in the logistics process flow of product from the supplier (manufacturer) to the final recipient (Choquet, 2010).

Model distribution system presupposes the existence of the structure of the system in the form of distribution channels, which are the "way to connect and the order in which they appear intermediaries, through which one or more streams of goods" (Garbarski, Rutkowski, Wrzosek, 2000), or "a set of interdependent organizations are involved in the delivery of the product or service to the user" (Kotler, 1994; Stern, El-Ansary, Coughlan, 2002; Czubała, 2001).

Clarifying the distribution channels in a subjective aspect enables to specify its structure, according to two criteria: ownership and participating in a physical movement. Thus, the structure of the distribution channel is as follows (Stern, El-Ansary, Coughlan, 2002):

- participates in the physical movement of goods through the provision of transport, storage or order handling services, transferring ownership rights to individual, downstream producers, wholesalers, individual or institutional customers,

- participants participating in the physical movement of goods but not gaining the right to property during their distribution, such as agents, brokers or sales representatives, 
- entities not participating in the physical movement of goods, at the same time not affording the property rights, perform auxiliary functions for the above participants: transport companies, shipping companies, logistics and distribution centers, as well as banking, financial and insurance institutions.

Example configurations indirect distribution models take into account the type of the first participants, who both make buying and selling products, and communicate what ownership to them, Figure 1 shows.

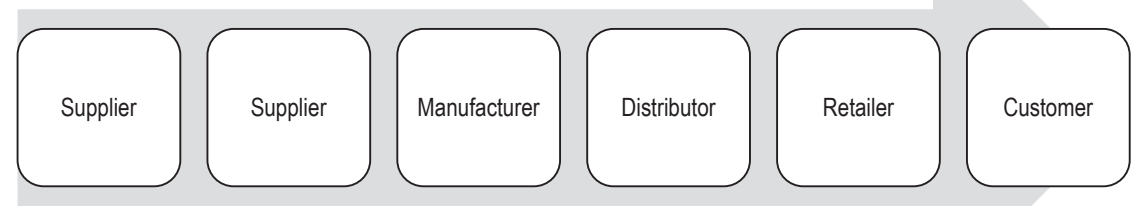

Figure 1. Exemplary scheme of the enterprise system

Source: Coyle, Bardi, Langley (2002).

The structure of the distribution channel used mainly determined by market factors, the properties and characteristics of the product, and the possibility of financial position of the manufacturer and the organizational and legal factors (Śliwczyński, Koliński, 2014).

The construction of the distribution system can be seen two major decision-making problems. The first one is related to the determination method of marketing, ie identifying types of distribution channels in terms of transaction volume. The second decision problem is associated with physical distribution, the choice way to move products from the places of production to places of destination (Gołembska, 2010).

The present scope of the decision related to the design of distribution channels includes findings on the following issues (Altkorn, 2004):

- channel type,

- number of channels,

- channel length,

- channel width,

- the type of participants.

The length of the distribution channel is measured by the number of levels or distribution levels, including more cells, forming a path between the producer and the end client.

Shaping the system seeks to ascertain, first of all, which entities, as well as the extent to which influence the structure and functioning of distribution channels specific products and the operation of the entire system. 


\section{Analysis of distribution services in the selected company distributing fertilizers}

Decisions related to the building of distribution channels can be both at the discretion of the manufacturer, wholesaler and retailer, but most often are taken by the manufacturer, because of the potential economic advantage. Manufacturer placing your product on the market can choose one or more channels. The choice of one channel can be justified by the individual characteristics of the product, which will decide on the unique control of its distribution. The advantage is the ease towards such a channel in the coordination and control of cooperative relations. A drawback of the low flexibility can be reacted fluctuations of demand and supply, and a low level of reliability, due to a limited number of embodiments of methods of sales (Bowersox, Cross, Cooper, 2006). Another situation caused by the desire to optimize costs through the use of outsourcing services, is taking over the responsibility for the traders distribution processes. The advantage of this solution is taken up by other parts of the cell risk of the product, so that the manufacturing company can concentrate on their "core business", and the development and improvement of the products. Horizontal channel system is the result of decisions about the number and types of intermediaries at the various levels of the channel, the result of it the following strategies for distributing the product on the market (Frankowska, Jedliński, 2011, Śliwczyński, Koliński, 2014):

- exclusive distribution is used to maintain a wide range of service level control by the manufacturer by significantly limiting the number of intermediaries in the channel,

- selective distribution includes selected intermediaries to reach a certain number of recipients, providing the manufacturer with complete control and low costs,

- intensive distribution is characterized by the placing of goods at all possible points of sale, thus enabling the purchase of large groups of buyers in widely accessible and convenient locations.

Constantly increasing competition in the market makes the company was still looking for opportunities to reduce costs of production and supply, and therefore more likely to purchase needed goods on the global market and to move the location of production to countries with low labor costs (offshoring). As a result, enterprise systems are becoming more complex, and the markets increasingly distant supplies. This situation makes it possible to reduce costs, but also increases the likelihood of failure to attain its objectives, thus forming a relationship of tradeoff, which is followed by reduction of operating costs while increasing the risk of various types of interference.

A similar situation occurs in the chemical industry, the fertilizer industry. Suppliers and manufacturers of raw materials procured are located in areas where access to raw materials, and thus the production and transport are cheaper. The market of mineral fertilizers in Poland has a particular specificity. On the demand side there is a large number of entities, while supply is represented mainly by units of the oligopolistic nature (Kapusta, 2003), hence, the market is regulating the flow of consumer products. Fertilizer industry is characterized by seasonality and weather changes that is determined by the current financial conditions of final consumers. In addition, modifying factor influencing the functioning of the chain will place the ordered product, the raw materials - the country imported Europe or the Far East.

Mineral fertilizers are delivered to the Polish market mainly through the national chemical industry. In trading with mineral fertilizers on the Polish market dominant role in the case of imports only play potassium fertilizers, because Poland does not have its own deposits of potassium salt. Business is conducted through intermediaries purchasing and distributing agricultural inputs for their own account and risk (Piwowar, 2008). Diagram of the distribution function on the mineral fertilizer market in Poland, determined on the basis of the analyzed company, is shown in Figure 2. 


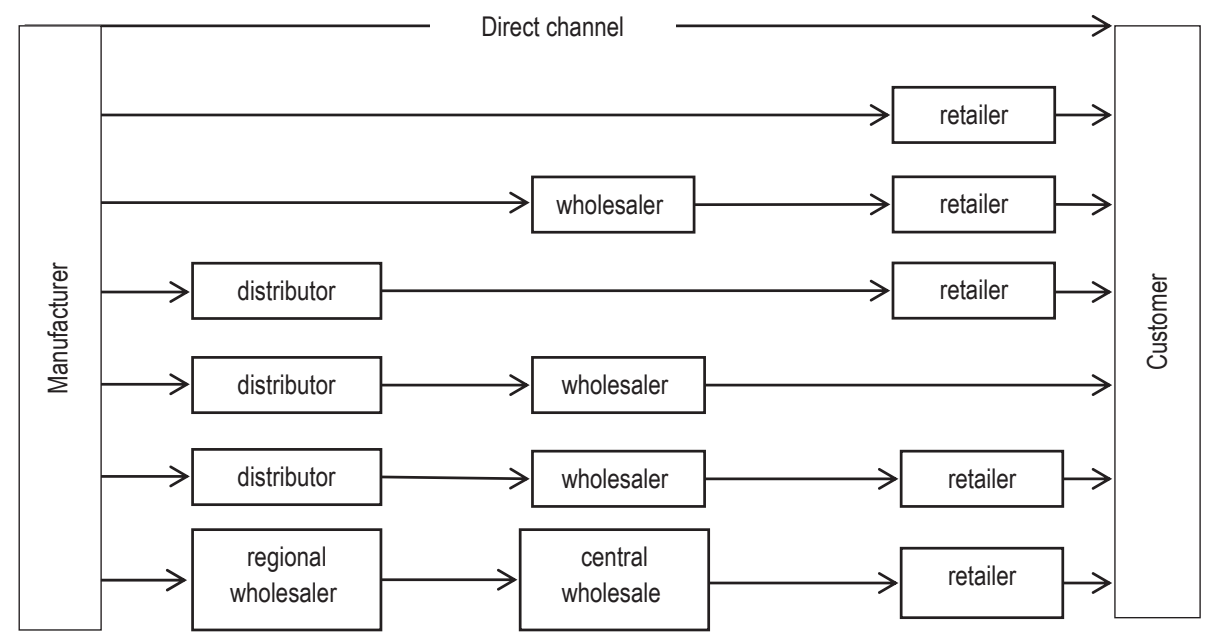

Figure 2. Examples of distribution models

Source: own study.

The results of the study showed that most companies offering the service of distribution of fertilizers in Poland mostly not direct sales and channel the most popular choice, it is a three-level distribution channel, as a distributor, wholesaler and retailer.

\section{Conclusions}

Building a distribution system in any industry is always subject to certain risks and uncertainties, because in such a complex system can often come across the events and phenomena bearing signs of randomness, which to the end can't be predicted due to unknown causes them. These challenges largely concerns the fertilizer industry, offering services where the distribution is also subject to weather risk, so the construction of such a system is particularly careful. Therefore, the company offering the service of distribution of fertilizers, opt for longer distribution systems, where it is possible to divide the possible risks. Companies must take action on many levels, create more and more opportunities for cooperation, and in building strategies into the future, but above all on the specific market of fertilizers must pay greater attention to the distribution system modeling and analysis of its environment, both closer and further.

\section{References}

Altkorn, J. (2004). Podstawy marketingu. Kraków: Instytut Marketingu.

Best, R.J. (2009). Market - Based Management. Prentice Hall PTR.

Bowersox, J.D., Cross, J., David Cooper, B.M. (2006). Supply Chain Logistics Management. McGrAw HIE.

Choquet, M. (2010). Logistyka dystrybucji. Poznań: Euro Logistics.

Coyle, J.J., Bardi, E.J., Langley, C.J. (2002). Zarzadzanie logistyczne. Warszawa: Wydawnictwo Naukowe PWN.

Czubała, A. (2001). Dystrybucja produktów. Warszawa: Wydawnictwo Naukowe PWN.

Frankowska, M., Jedliński, M. (2011). Efektywność systemu dystrybucji. Warszawa: PWE. 
Garbarski, L., Rutkowski, I., Wrzosek, W. (2000). Marketing. Punkt zwrotny nowoczesnej firmy. Warszawa: Wydawnictwo Naukowe PWN.

Gołembska, E. (2010). Kompendium wiedzy o logistyce. Warszawa: Wydawnictwo Naukowe PWN.

Kapusta, F. (2003). Teoria agrobiznesu. Wrocław: Wydawnictwo Akademii Ekonomicznej.

Kotler, P. (1994). Marketing, analiza, planowanie, wdrażanie i kontrola. Warszawa: Gebethner \& Ska.

Kramer, T. (2004). Podstawy marketingu. Warszawa: PWE.

Piwowar, A. (2008). Zużycie i relacje cenowe wybranych nawozów mineralnych do ziarna pszenicy. Journal of Agribusiness and Rural Development, 2.

Stern, L.W., El-Ansary, A.I., Coughlan, A.T. (2002). Kanały marketingowe. Warszawa: Wydawnictwo Naukowe PWN.

Sztucki, T. (2000). Marketing przedsiębiorcy i menadżera. Warszawa: Agencja wydawnicza Placet.

Śliwczyński, B., Koliński, A. (2014). Organizacja i monitorowanie procesów dystrybucji. Poznań: Instytut Logistyki i Magazynowania.

Cite this article aS: Matuszczak, A. (2018). Analysis of the distribution system construction company offering the service of distribution of fertilizer. European Journal of Service Management, 2 (26), 161-166. DOI: 10.18276/ejsm.2018.26-20. 